\title{
Maize (Zea mays) Intercropping with Legumes Enhances Growth, Dry Matter and its Forage Yield under Deficit Irrigation
}

\author{
Muhammad Aslam ${ }^{1 * \dagger}$, Muhammad Naeem ${ }^{1 \dagger}$, Abdul Rehman ${ }^{2,3}$, Muhammad Mubashar Zafar ${ }^{4}$, Rashid Iqbal ${ }^{1}$, \\ Muhammad Ayaz Shahzad ${ }^{1}$, Rana Muhammad Ikram Khan ${ }^{1}$ and Javed Iqbal ${ }^{1}$ \\ ${ }^{1}$ Department of Agronomy, Faculty of Agriculture and Environment, The Islamia University of Bahawalpur, 63100, Pakistan \\ ${ }^{2}$ Zhengzhou Research Base, State Key Laboratory of Cotton Biology, Zhengzhou University, Zhengzhou 450000, China \\ ${ }^{3}$ Institute of Cotton Research, Chinese Academy of Agricultural Sciences, Anyang 455000, China \\ ${ }^{4}$ State Key Laboratory of Cotton Biology, Key Laboratory of Biological and Genetic Breeding of Cotton, The Ministry of \\ Agriculture, Institute of Cotton Research, Chinese Academy of Agricultural Science, Anyang, 455000, Henan, China \\ *For correspondence: aslam1302@gmail.com; aslam1302@yahoo.com \\ ${ }^{\dagger}$ Contributed equally to this work and are co-first authors \\ Received 25 July 2020; Accepted 04 September 2020; Published 10 December 2020
}

\begin{abstract}
Climate change is one of the serious threats to agriculture and livestock. Climate change induced and reduced water shortage lowers production of food and fodder crops. In order to investigate the effects of deficit irrigation on forage yield of maize (Zea mays L.), cowpea (Vigna unguiculata L.), and guar (Cyamopsis tetragonoloba L.) grown as sole or intercropping of maize with cowpea and guar, the fields experiments were conducted during spring 2016 and 2017 in randomized complete block design (RCBD) with split plot arrangement. These crops were further exposed to water deficit by skipping irrigation at crop stages following maize growth scale at 15 days (V4), 30 days (V6), 45 days (V9), and 60 days (V12) after sowing along with normal irrigation. Maize intercropped with guar had maximum leaf area, plant height land equivalent ratio and monetary advantage index at normal irrigation but did not differ significantly under deficit irrigation. Thus, maize intercropped with guar was found more productive and beneficial with respect to sole under deficit irrigation. (C) 2021 Friends Science Publishers
\end{abstract}

Key words: Cowpea; Forage; Guar; Intercropping; Maize; Yield

\section{Introduction}

Sustainable agriculture based on the provision of food security, enhanced quantity and quality of agriculture produces to satisfy the demand of increasing population (Eskandari 2012). Livestock though the mainstay of agriculture sector has remained a neglected sector for years. Various factors are responsible for low productivity of dairy animals regarding milk and meat production. The nonprovision of quality forages is the single main factor that squelches the animal's productivity (Iqbal et al. 1999). Moreover, the availability of quality fodder to the livestock is contributed to sustainable milk and meat production (Ginwal et al. 2019). Therefore, in order to keep the livestock's productivity up, it is much needed to increase supply of quality forage/fodder (Iqbal and Iqbal 2015).

Forages are considered most reliable and nutritious source of animal feed resource. The term forage represents all the plant materials in succulent and green form while the term fodder represents the dried form of feed such as silage and hay. Cereals forages such as millet (Panicum miliaceum
L.), maize (Zea mays L.), and sorghum (Sorghum bicolor L.), are important source of animals feed but have less protein contents. Compared to the cereals, legume forages such as soybean (Glycine max L.), cow pea (Vigna unguniculata L.), cluster bean (Cyamopsis tetragonoloba L.) are more protenious but their yield per unit area is a matter of concern (Bhagmal et al. 2009). Growing of legumes with cereals crops is productive and evolves as profitable cropping system over solitary cropping (Evans et al. 2001). Growing of mixed crop would enhance the production on the given area, and economic resources utilization (Marer et al. 2007). Legumes fix the atmospheric nitrogen, improve soil fertility, and are also a good source of nitrogen for cereal crops (Manna et al. 2003). Growing of cereals with legumes is best way for the availability of nitrogen to the neighbor crop (Connolly et al. 2001). When legumes are intercropped with cereals, it improves the utilization of available resource for maximizing yield (Khonde et al. 2018).

Water is a limiting factor in dry areas. Deficit irrigation has been evolved a way not only to save the water 
but an important tool to get optimum yield. The effect of deficit irrigation is non-significant if applied on less sensitive growth stages of the crop (Moutonnet 2002). When maize crop receives three irrigations with the depth of $150 \mathrm{~mm}$ for each at vegetative, tasseling and grain filling stages, it would produce higher yield (Fentawa 2006). Maize can be intercropped with legumes to feed the animals at any stage without risk of any ingredient i.e., prussic acid and oxalic acid (Dahmardeh et al. 2009).

When cereals like wheat and barley (Hordeum vulgare L.) are intercropped with legumes like fababean (Vicia faba L.), and rapeseed (Brassica napus L.) under deficit irrigation, the yield of the cereals is not affected (Amanullah et al. 2020). When maize is intercropped with legumes under deficit irrigation, the yield of maize is also not significantly affected (Sani et al. 2014).

Various studies have been conducted to explore yield/economic advantages of the intercropping but to find a suitable combination of cereal and legumes to get optimum yield and forage quality under deficit irrigation has not been explored to its full potential. Therefore, to explore this area of research, three spring fodders viz., maize, cowpea, and guar were grown as sole crops and intercropping of maize with cow pea and guar under deficit irrigation and the impact of deficit irrigation was evaluated on the forage yield of the crops.

\section{Materials and Methods}

Experiment was carried out at experimental area Department of Agronomy, Faculty of Agriculture and Environment, The Islamia University of Bahawalpur, Pakistan (Latitude, $29^{\circ}$ $23^{\prime} 60.00 " \mathrm{~N}$, Longitude, $71^{\circ} 40^{\prime} 59.99 " \mathrm{E}$ ). The soil of experimental area was analyzed before sowing the crops. The soil was found to be sandy loam type. The soil samples were taken from $0-15 \mathrm{~cm}$ and 16-30 cm depth. The soil physico-chemical properties of experimental area were analyzed at Soil and Water Testing Laboratory Regional Agriculture Research Institute Bahawalpur, Pakistan during 2016 and 2017 are given in Table 1.

The seeds of three spring fodders i.e. maize variety 'Neelam', local variety of guar 'desi', and local variety of cowpea 'rawaan' were collected from Ayub Agricultural Research Institute, Faisalabad, Pakistan and sown on February 15, 2016 and 2017, as sole maize, cowpea, and guar and intercropping of maize with cowpea and guar respectively, maintaining seed ratio of 70:30 for each combination (Azim et al. 2000).

The sole crops and their combinations were subjected to four water deficit irrigation regimes along with control applied at different interval days in the following manners: Normal Irrigation, V4= Four leaves development stage (15 days after sowing), V6= Six leaves development stage $(30$ days after sowing), V9= Nine leaves development stage (45 days after sowing), and V12=Twelve leaves development stage (60 days after sowing). The treatments were replicated three times using randomized complete block design (RCBD) under split plot design with net plot size of $3 \mathrm{~m} \times 6$ $\mathrm{m}$. A fine seed bed was prepared by four ploughing followed by planking. Seeds were sown through hand drill on ridges maintaining row to row distance of $30 \mathrm{~cm}$ and legumes intercropped in alternate rows of maize. Fertilizer was applied at $112.50 \mathrm{~kg} \mathrm{~N}$ and $50 \mathrm{~kg} \mathrm{P}_{2} \mathrm{O}_{5} \mathrm{ha}^{-1}$ in each plot. The $1 / 2$ of the nitrogen and whole phosphorous was applied as basal dose and remaining nitrogen was applied at succeeding irrigation. Seed rate for maize, cowpea and guar was used at the rate of 100,30 , and $50 \mathrm{~kg} \mathrm{ha}^{-1}$ respectively. Maize crop was harvested at heading stage approximately 75 days after sowing (at least 35\% dry matter) for green fodder. Legume fodders were harvested at early pod formation stage (8 weeks after sowing) (Azim et al. 2000; Iqbal et al. 2006).

Data regarding average environmental temperature and rainfall during field experiment in 2016 and 2017 was recorded respectively (Table 2 ).

\section{Growth and yield parameters}

Leaf area $(\mathrm{cm})$ per plant was measured with the help of formula; $\mathrm{LA}=\mathrm{LW} \times \mathrm{A}$. Where $\mathrm{LA}$ is leaf area, $\mathrm{L}$ is leaf maximum length, and $\mathrm{W}$ is leaf maximum width and $\mathrm{A}$ is constant respectively. The value of the constant (A) is 0.75 (Montgomery 1911). A quadrant with dimension $1 \mathrm{~m} \times 1$ $\mathrm{m}$ was used while taking the sample from each plot. Number of plants (stand density; $\mathrm{m}^{-2}$ ) was calculated in area (Khan et al. 2014). Height of harvested plants $(\mathrm{cm})$ of each crop was measured at maturity by taking five plants from each plot selected randomly with the help of meter rod (Khan et al. 2014). The randomly selected plants in the given area were separated and counted number of leaves per plant (Khan et al. 2014).

\section{Competition indices}

Land equivalent ration was measured with following formula: LER: (LER maize + LER legume). Where LER maize: (Yml /Ym) and LER legume: Ylm / Yl. Where Ym was yield of sole maize crop and $\mathrm{Yl}$ was yields of sole legumes crops, respectively. Yml was yield of maize intercrop and Ylm was yield of legumes intercrops respectively (Machet et al. 1997). The value of relative crowding coefficient $(\mathrm{K})$ was calculated with following formula: K: (Kmaize $\times$ Klegume), Where Kmaize: Yml $\times$ $\mathrm{Zlm} /(\mathrm{Ym}-\mathrm{Yml}) \times \mathrm{Zml})$, and Klegume: Ylm $\times \mathrm{Zml} /(\mathrm{Yl}-$ Ylm) $\times$ Zlm). Where Zml and Zlm are the proportions of maize and legume in the mixture respectively (Dhima et al. 2007). Aggressivity (A) was measured as: Amaize $=(\mathrm{Yml} /$ $\mathrm{Ym} \times \mathrm{Zml})-(\mathrm{Ylm} / \mathrm{Yl} \times \mathrm{Zlm})$ and Alegume $=(\mathrm{Ylm} / \mathrm{Yl} \times$ Zlm) - (Yml / Ym $\times$ Zml) (Dhima et al. 2007). Competitive ratio (CR) was calculated with formula: CRmaize = (LERmaize / LERlegume) (Zlegume-maize / Zmaizelegume), and CRlegume = (LERlegume / LERmaize) (Zmaize-legume / Zlegume-maize) (Tsubo et al. 2005). Actual yield loss index (AYLI) was calculated as: AYL = 
Enhancing Forage Yield under Deficit Irrigation / Intl J Agric Biol, Vol 25, No 1, 2021

Table 1: Physico-chemical analysis of experimental soil

\begin{tabular}{|c|c|c|c|c|c|c|}
\hline \multirow[t]{2}{*}{ Description } & \multicolumn{3}{|c|}{2016} & \multicolumn{3}{|c|}{2017} \\
\hline & & Values & Status & & lues & Status \\
\hline Depth & $0-15 \mathrm{~cm}$ & $16-30 \mathrm{~cm}$ & & $0-15 \mathrm{~cm}$ & $16-30 \mathrm{~cm}$ & \\
\hline Texture & sandy loam & & & Sandy loam & & \\
\hline Sand percentage & 41 & 38 & & 39 & 37 & \\
\hline Silt percentage & 35 & 36 & & 36 & 37 & \\
\hline Clay percentage & 24 & 26 & & 25 & 26 & \\
\hline Chemical analysis & $0-15 \mathrm{~cm}$ & $16-30 \mathrm{~cm}$ & & $0-15 \mathrm{~cm}$ & $16-30 \mathrm{~cm}$ & \\
\hline EC & $1.30 \mathrm{dS} \mathrm{m}^{-1}$ & $1.28 \mathrm{dS} \mathrm{m}^{-1}$ & Normal & $1.34 \mathrm{dS} \mathrm{m}^{-1}$ & $1.29 \mathrm{dS} \mathrm{m}^{-1}$ & Normal \\
\hline $\mathrm{pH}$ & 8.7 & 8.9 & Alkaline & 8.6 & 8.4 & Alkaline \\
\hline Organic matter & $0.93 \%$ & $0.91 \%$ & Deficient & $0.98 \%$ & $0.95 \%$ & Deficient \\
\hline $\mathrm{P}$ & $16.90 \mathrm{mg} \mathrm{kg}^{-1}$ & $16.71 \mathrm{mg} \mathrm{kg}^{-1}$ & Deficient & $17.12 \mathrm{mg} \mathrm{kg}^{-1}$ & $17.09 \mathrm{mg} \mathrm{kg}^{-1}$ & Deficient \\
\hline $\mathrm{N}$ & $0.016 \mathrm{mg} \mathrm{kg}^{-1}$ & $0.017 \mathrm{mg} \mathrm{kg}^{-1}$ & Deficient & $0.017 \mathrm{mg} \mathrm{kg}^{-1}$ & $0.018 \mathrm{mg} \mathrm{kg}^{-1}$ & Deficient \\
\hline $\mathrm{K}$ & $125 \mathrm{mg} \mathrm{kg}^{-1}$ & $126 \mathrm{mg} \mathrm{kg}^{-1}$ & Sufficient & $126 \mathrm{mg} \mathrm{kg}^{-1}$ & $127 \mathrm{mg} \mathrm{kg}^{-1}$ & Medium \\
\hline
\end{tabular}

Table 2: Average monthly temperature and rainfall during experimental duration (2016 and 2017)

\begin{tabular}{llll}
\hline Years & Months & Temperature $\left({ }^{\circ} \mathrm{C}\right)$ & Rainfall $(\mathrm{mm})$ \\
\hline 2016 & February & 20 & 12.2 \\
& March & 25 & 14.1 \\
& April & 30 & 16.5 \\
& May & 32 & 18.1 \\
& February & 12 & 4.2 \\
& March & 20 & 12.3 \\
& April & 25 & 10.3 \\
& May & 16 & 8.5 \\
\hline
\end{tabular}

AYLmaize + AYLlegume. Where AYL maize $=\{(\mathrm{Yml} / \mathrm{Zml})$ $(\mathrm{Ym} / \mathrm{Zm})\}-1$ and $\mathrm{AYL} \mathrm{l}_{\text {legume }}=\{(\mathrm{Ylm} / \mathrm{Zlm})(\mathrm{Yl} / \mathrm{Zl})\}-1$ (Banik and Sharma 2009). Monetary advantage index (MAI) describes economic advantages of intercropping. It can be calculated by using following formula: MAI: (value of combined intercrops) (LER-1) / LER. Higher value of MAI results in profitable intercropping (Ghosh 2004). Intercropping advantage (IA) describes economic feasibility of intercropping and measured as: IAmazie: AYLmazie $x$ Pmaize where IAlegume: AYLlegume $\times$ Plegume. Commercial values of legumes and maize are denoted by Pmaize and Plegume respectively (Banik et al. 2000). After harvesting plants from every plot with the help of sickle, their $\left(\mathrm{t} \mathrm{ha}^{-1}\right)$ weight was measured by spring balance (Iqbal et al. 2006). The dry matter yield was calculated with the help of formula; Dry matter (\%): Dry weight/Fresh weight $x$ 100 and Dry matter yield: Forage yield of related crop $\times$ dry matter (\%) of that crop (Iqbal et al. 2006).

\section{Statistical analysis}

Data were analyzed statistically by using Fisher's analysis of variance techniques using STATISTIX software and the differences among the treatment means were compared according to Least Significant Difference (LSD) at 5\% probability (Steel et al. 1997).

\section{Results}

\section{Growth and yield parameters}

Leaf area per plant, stand density, green forage and dry matter yield of sole maize and intercrops were affected significantly by different levels of irrigation during both years respectively. Maximum leaf area per plant was exhibited by maize intercropped with guar at normal irrigation during both years while minimum leaf area per plant was exhibited by sole maize for irrigation skipped 45 and 60 days after sowing, respectively. Sole maize achieved maximum stand density, green forage and dry matter yield at normal irrigation with respects to its intercrop (Table 3).

Leaf area per plant, plant height, stand density, green forage and dry matter yield of cowpea grown as sole and intercropped with maize were affected significantly at each irrigation level during both years respectively. Maximum leaf area per plant was achieved by cowpea intercropped with maize at normal irrigation while sole cowpea resulted in minimum leaf area per plant at same level of irrigation. Maximum plant height was exhibited by sole cowpea at normal irrigation and minimum plant height was achieved by cowpea intercrop for irrigation skipped 15 and 30 days after sowing, respectively. Maximum stand density, green forage and dry matter yield were exhibited by sole cowpea at normal irrigation while minimum for irrigation skipped 15 and 30 days after sowing while minimum green forage yield for irrigation skipped 30 and 60 days after sowing and dry matter yield for irrigation skipped 45 days after sowing by cowpea intercropped with maize respectively (Table 4 ).

Leaf area per plant, plant height, stand density, green forage and dry matter yield of sole guar and intercrop were affected significantly by all irrigation levels during both years, respectively. Maximum leaf area per plant and plant height were achieved by guar intercrop and sole at normal 
Aslam et al. / Intl J Agric Biol, Vol 25, No 1, 2021

Table 3: Effect of different irrigation regimes on growth and yield parameters of maize grown as sole and intercropped with cowpea and guar

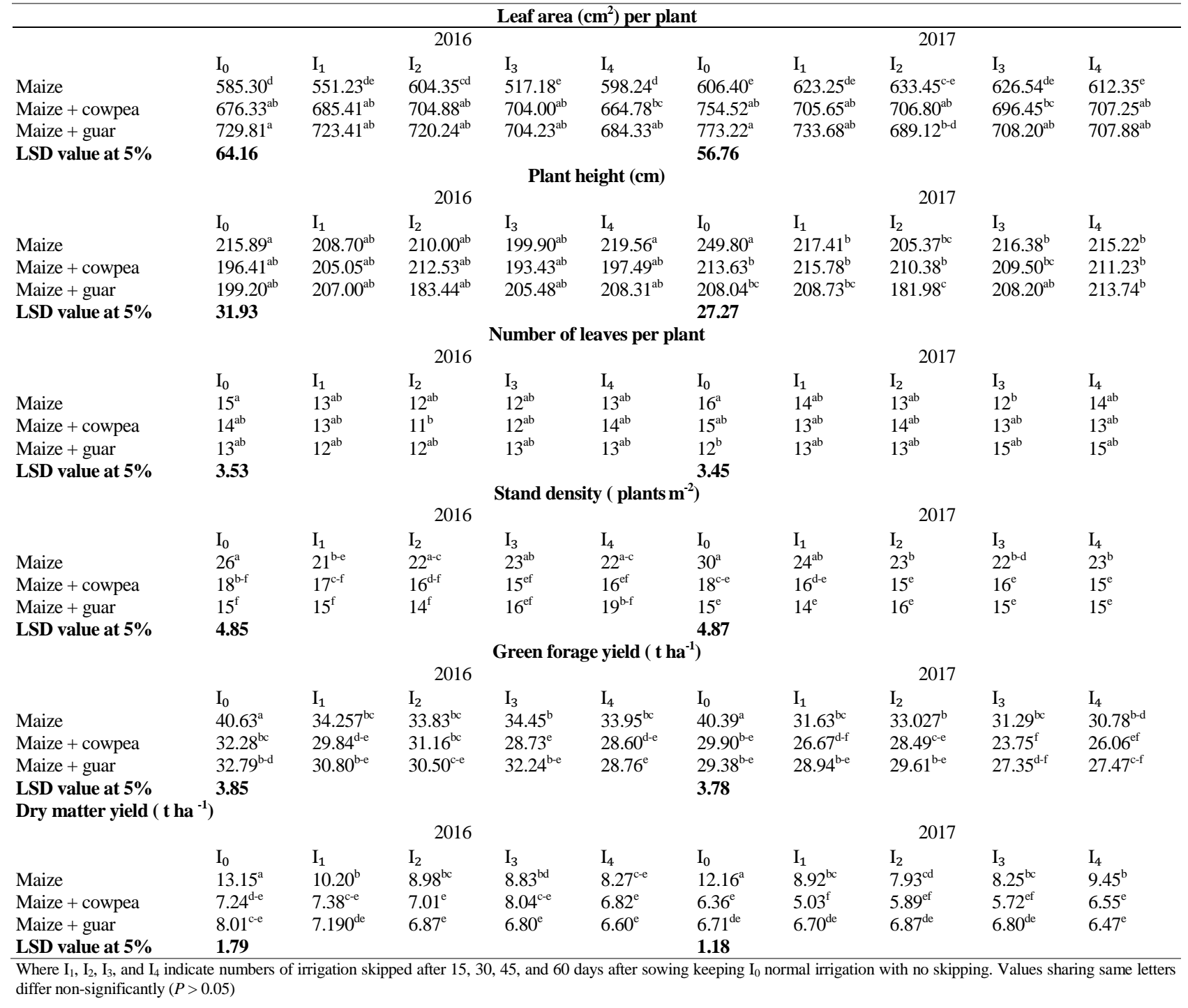

irrigation while minimum leaf area per plant for irrigation skipped 15 and 30 days after sowing and minimum plant height for irrigation skipped 60 and 45 days after sowing was achieved by sole guar respectively. Sole guar had stand density, green forage and dry matter yield at normal irrigation. The lowest stand density for irrigation skipped 45 and 30 days after sowing and lowest green forage and dry matter yield for irrigation skipped 60 days after sowing were achieved by guar intercrop. Maximum number of leaves per plant was achieved by sole guar at normal irrigation and minimum number of leaves per plant was exhibited by guar intercrop for irrigation skipped 15 and 45 days after sowing respectively (Table 5).

\section{Competition indices}

Maize showed dominance in maize: cowpea and maize: guar intercropping combinations as it showed higher values of land equivalent ratio (LER), relative crowding coefficient (K), aggressivity (A), competition ratio (CR), actual yield loss index (AYLI), intercropping advantage (IA) at each irrigation level than cowpea and guar intercrops during both years respectively. The highest values of LER were recorded for maize-guar intercropping with guar at normal irrigation and minimum land equivalent ratio (LER) were recorded for irrigation skipped 30 and 15 days after sowing for maize-cowpea intercropping, respectively. It showed the economic advantages of maize-guar intercropping over maize-cowpea intercropping. Moreover, LER values of maize-guar intercropping did not differ significantly to each other at each irrigation level. Higher values of relative crowding co-efficient $(\mathrm{K})$ for maize: guar intercropping were observed at normal irrigation while maize-cowpea resulted in minimum $\mathrm{K}$ values for irrigation 
Enhancing Forage Yield under Deficit Irrigation / Intl J Agric Biol, Vol 25, No 1, 2021

Table 4: Effect of different irrigation regimes on growth and yield parameters of cowpea grown as sole and intercropped with maize

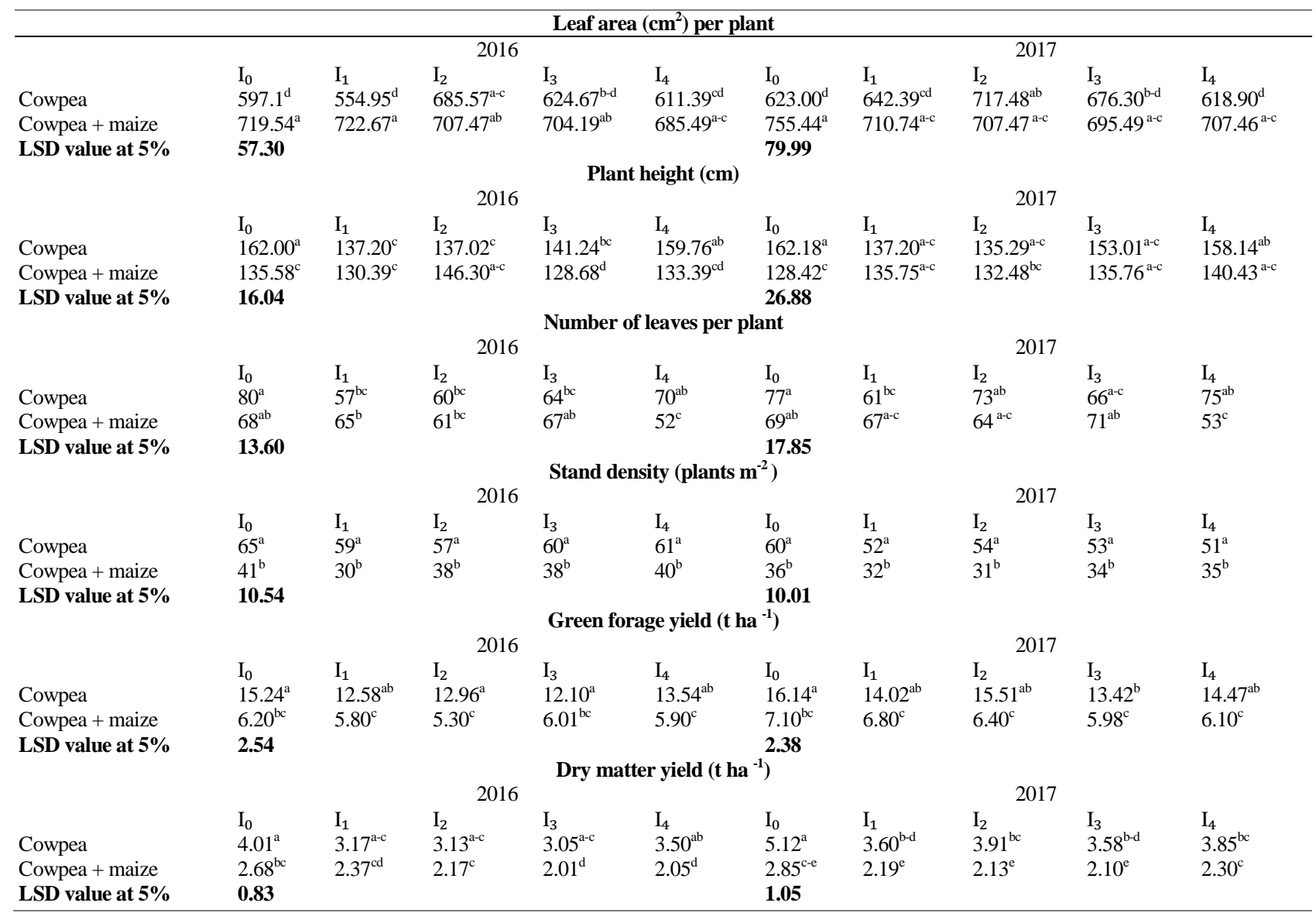

Where $\mathrm{I}_{1}, \mathrm{I}_{2}, \mathrm{I}_{3}$, and $\mathrm{I}_{4}$ indicate numbers of irrigation skipped after 15, 30, 45, and 60 days after sowing keeping $\mathrm{I}_{0}$ normal irrigation with no skipping. Values sharing same letters differ non-significantly $(P>0.05)$

skipped 15 days after sowing respectively that showed better performance over maize-cowpea intercropping. Different values of aggressivity (A) indicate that companion crops did not show equal competition and maize showed higher value to dominate over other intercrops. Higher values of A of maize-cowpea intercropping were recorded at normal irrigation as compared to A values of maize-guar intercropping that achieved minimum for irrigation skipped 15 and 45 days after sowing, respectively. Maximum values of competition ratio (CR) of maize were recorded at normal irrigation that showed its dominance over intercrops. Moreover maize-cowpea intercropping achieved higher values of $\mathrm{CR}$ at normal irrigation while minimum $\mathrm{CR}$ values of maize-guar intercropping were observed for irrigation skipped 30 and 60 days after sowing, respectively. Higher positive values of actual yield loss index (AYLI) of maize were observed at each irrigation level as compared to negative AYLI values of intercrops while maize-guar intercropping showed maximum values of AYLI at normal irrigation as compared to the minimum AYLI values of maize-cowpea intercropping for irrigation skipped 15 and 30 days after sowing respectively. Overall all positive values of AYLI indicate the economic advantages of intercropping. Likewise, maize resulted in to higher positive values of intercropping advantage (IA) at all irrigation levels as compared to negative IA values of intercrops and maizeguar intercropping resulted in to higher values of IA at normal irrigation as compared to the minimum IA values of maize-cowpea for irrigation skipped 30 and 45 days after sowing respectively. Over all positive values of IA showed the beneficial effects of intercropping. Maize-guar intercropping resulted in the highest values of monetary advantage index (MAI) at normal irrigation while minimum MAI values of maize-cowpea intercropping were achieved for irrigation skipping 15 days after sowing respectively that resulted in higher economic advantages with respect to maize-cowpea intercropping. Moreover, the values of MAI did not significantly affect at each irrigation level and resulted in the economic advantages of intercropping under deficit irrigation (Table 6).

\section{Discussion}

Leaf area per plant, stand density, green forage and dry matter yield of sole maize and intercrops were significantly affected during both years (Table 3). The higher values of 
Aslam et al. / Intl J Agric Biol, Vol 25, No 1, 2021

Table 5: Effect of different irrigation regimes on growth and yield parameters of guar grown as sole and intercropped with maize

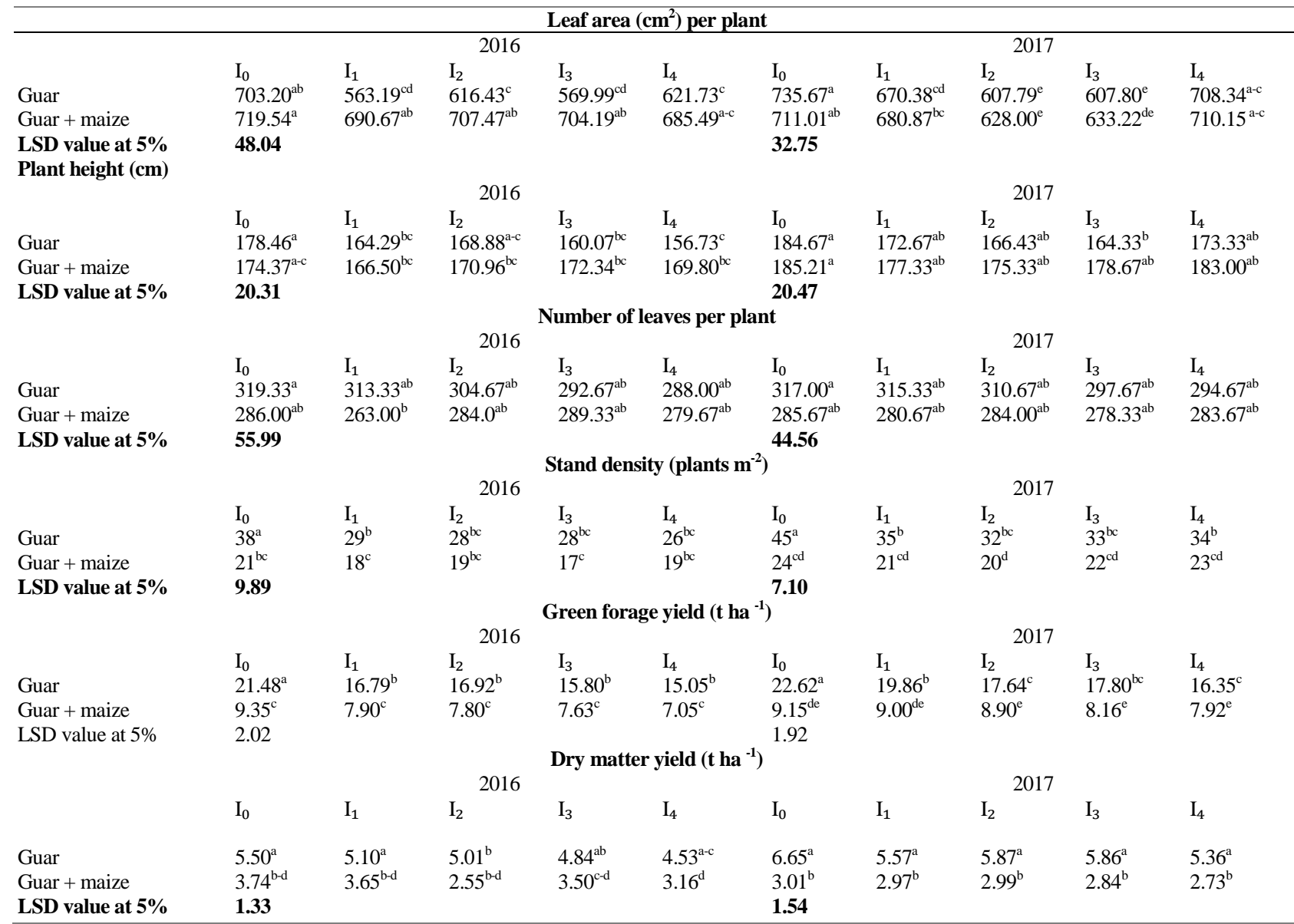

Where $\mathrm{I}_{1}, \mathrm{I}_{2}, \mathrm{I}_{3}$, and $\mathrm{I}_{4}$ indicate numbers of irrigation skipped after 15, 30, 45, and 60 days after sowing keeping $\mathrm{I}_{0}$ normal irrigation with no skipping. Values sharing same letters differ non-significantly $(P>0.05)$

leaf area per plant were recorded for maize-guar intercropping at normal irrigation. The higher leaf area is due to the beneficial effects of legumes intercrop over the companion crops as the former help to fix atmospheric nitrogen, increases over all productivity of the intercrops and higher leaf area contributed to maximum interception of light, utilized in photosynthesis which resulted in maximum forage yield (Nasrollahzadeh and Koohi 2014; Ginwal et al. 2019). The maximum stand density, green forage and dry matter yield were achieved by the sole maize during the same years at same irrigation level that might be due to the higher seed rate used for sole maize as compared to low seed rate with 70:30 for maize and cowpea intercrop respectively. This resulted in higher plant population, green forage and dry matter yield for sole maize as compared to maize intercrop (Khan et al. 2012). The leaf area per plant and plant height obtained under normal irrigation were not significantly differed as compared to under deficit irrigation. Sole cowpea and guar achieved maximum values of leaf area per plant, stand density, green forage and dry matter yield during both years as compared to intercrops. The higher leaf area of cowpea and guar was achieved due to non-competing effect of the intercrops (Abate and Alemayehu 2018; Yang et al. 2018). While higher stand density, green forage and dry matter yield was due to higher seed rate used for sole cowpea and guar as compared to the seed rate with 70:30 in intercropping with maize as higher seed rate contributed to maximum plant population and biological yield for sole cowpea and guar as compared to intercrops (Khan et al. 2012) (Table 3 and 4).

Land equivalent ratio (LER) measure the effectiveness of intercropping over mono-cropping to utilize environmental resources and its value greater than one, equal to one or less than one indicate more yield, same or less yield respectively (Khonde et al. 2018). The maize-guar intercropping resulted in maximum LER during both years and showed its advantages over maize-cowpea intercropping that might be due to effective and efficient utilization of natural resources like land and light (Yang et al. 2018). The relative dominance of one species over the other in a mixture is known as relative crowding co-efficient (K) and crop with higher value of $\mathrm{K}$, the more dominant effect it would have over companion crop (Takim 2012). The results revealed that the partial $\mathrm{K}$ values of maize were 
Enhancing Forage Yield under Deficit Irrigation / Intl J Agric Biol, Vol 25, No 1, 2021

Table 6: Effect of different irrigation regimes on competition indices of maize intercropped with cowpea and guar

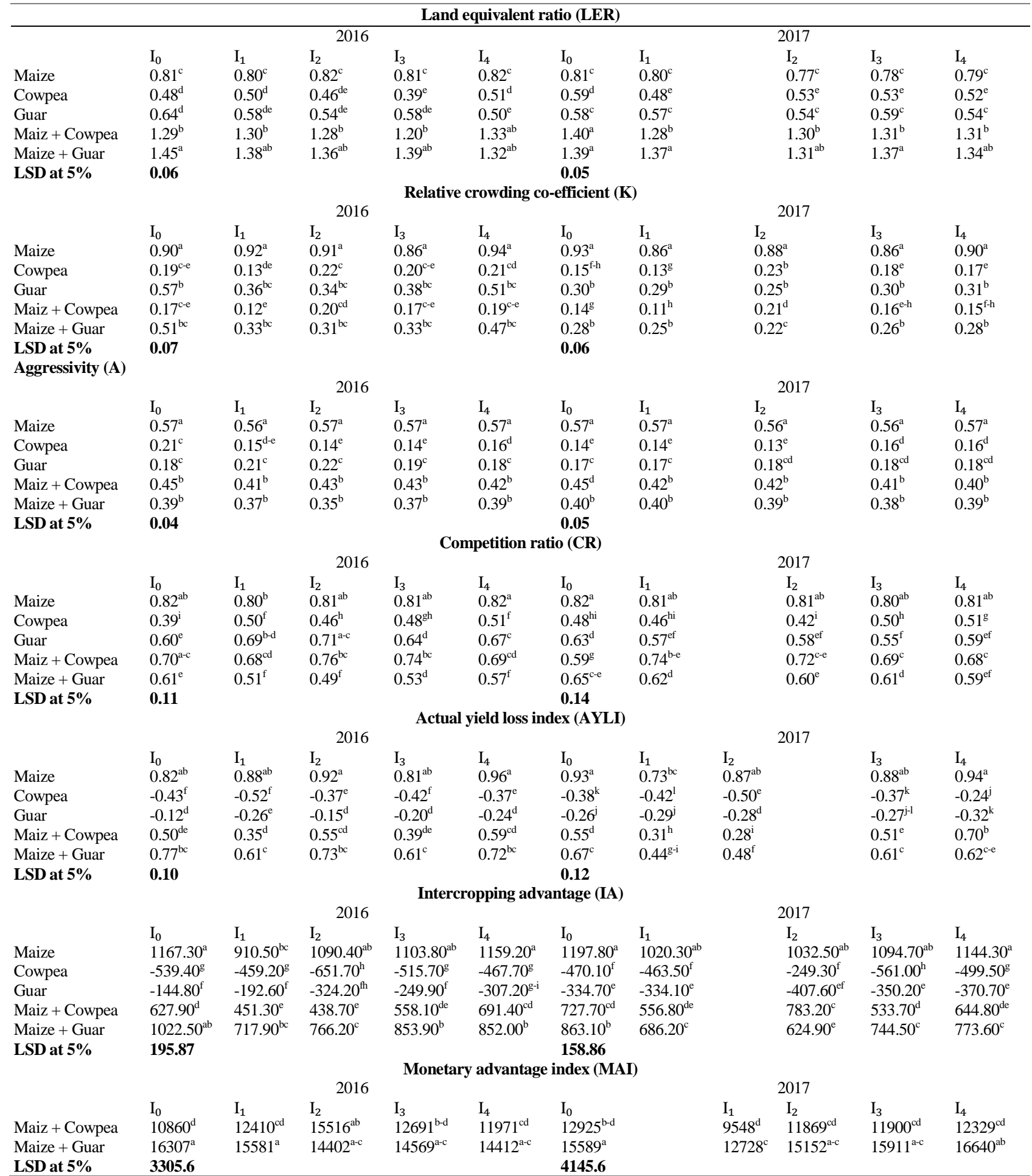

Where $\mathrm{I}_{1}, \mathrm{I}_{2}, \mathrm{I}_{3}$, and $\mathrm{I}_{4}$ indicate numbers of irrigation skipped after 15, 30, 45, and 60 days after sowing keeping $\mathrm{I}_{0}$ normal irrigation with no skipping. Values sharing same letters differ non-significantly $(P>0.05)$

greater than the partial $\mathrm{K}$ values of cowpea and guar during both years which showed competitive advantage of the maize over intercrops and maize intercropped with guar resulted in maximum $\mathrm{K}$ values as compared to its intercropping with cowpea (Khonde et al. 2018). The relative competitive ability of one crop as compared to other when cultivated in combination with that crop can be described with the help of aggressivity (A). If the value of $A$ 
is either zero (0), or positive (above zero), and/or negative (less than zero) then both crops would be equally competitive, or one crop is dominant or weak in competition respectively (Jan et al. 2016). During both years of the experiment, the partial values of A of maize were greater than intercrops that showed the dominance of maize over cowpea and guar (Imran et al. 2011). It is clearly shown from the experiment that partial values of $\mathrm{CR}$ of maize were greater than intercrops during both years which resulted in competitive advantage of maize over cowpea and guar showing higher ability to utilize environmental resources efficiently (Javanmard et al. 2014). The proportionate yield advantage (gain) or disadvantage (loss) of intercrops as compared to sole crops is described as actual yield loss index (AYLI). It is derived from the experiment maize showed partial positive values of AYLI that resulted in yield advantages while partial values of AYLI of intercrops were negative that showed the yield disadvantages. Maize-guar resulted in maximum values of AYLI during both years of the experiment as compared to maize-cowpea intercropping (Takim 2012). The economic feasibility of intercropping is termed as intercropping advantage (IA). It is observed from the experiment that maize showed positive values of IA as compared to intercrops which showed negative values. However, over all positive IA values were recorded which showed the advantages of intercropping over solitary cultivation. Maize intercropped with guar resulted in maximum values of IA during experimental duration that resulted in to more feasible option of intercropping as compared to guar (Takim 2012). Monetary advantage index (MAI) describes economic advantages of intercropping. Maize-guar intercropping resulted in maximum values of MAI as compared to MAI values of maize-cowpea intercropping that showed its higher economic advantage over maize-cowpea intercropping under deficit irrigation during both years (Tofa et al. 2017) (Table 6).

\section{Conclusion}

This research study concludes that maize intercropped with cowpea and guar reduced the yield as compared to their sole cultivation but overall productivity in terms of leaf area, plant height, land equivalent ratio, and monetary advantage index were recorded in maize: guar intercropping under deficit irrigation and it did not differ significantly with respect to normal irrigation. So, maize: guar intercropping was found a suitable cropping combination under hot climate where farmer face scarcity of irrigation water.

\section{Author Contributions}

MA and MN planned, conduct, and write the initial results/draft of the experiment, AR and MMZ reviewed the results, RI, MAS, RMIK and JI statistically analyzed the data and made illustrations.

\section{References}

Abate M, G Alemayehu (2018). Biological benefits of intercropping maize (Zea mays L.) with fenugreek, field pea and haricot bean under irrigation in fogera plain, south gonder zone, Ethiopia. Agric For Fish 7:19-35

Amanullah, K Shah, F Khalil (2020). Influence of irrigation regimes on competition indexes of winter and summer intercropping system under semi-arid regions of Pakistan. Sci Rep10; Article 8129

Azim A, AG Khan, MA Nadeem, D Muhammad (2000). Influence of maize and cowpea intercropping on fodder production and characteristics of silage. Asian-Aust J Anim Sci 13:781-784

Banik P, RC Sharma (2009). Yield and resource utilization efficiency in baby corn-legume-intercropping system in the eastern plateau of India. J Sustain Agric 33:379-395

Banik P, T Sasmal, PK Ghosal PK, DK Bagchi (2000). Evaluation of mustard (Brassica compestris L. Var. Toria) and legume intercropping under $1: 1$ and 2:1 row-replacement series systems. $J$ Agron Crop Sci 185:9-14

Bhagmal, K.A Singh, A Roy, A Shahid, M Devendra (2009). Forage Crops and Grasses. In: Handbook of Agriculture, pp:1353-1417. Directorate of Information and Publications of Agriculture, Indian Council of Agricultural Research, New Delhi, India

Connolly J,HCGoma, K Rahim (2001). The information content of indicators in intercropping research. Agric Ecosyst Environ 87:191-207

Dahmardeh M, A Ghanbari, B Syasar, M Ramroudi (2009). Effect of intercropping maize (Zea mays L.) with cow pea (Vigna unguiculata L.) on green forage yield and quality evaluation. Asian J Plant Sci 8:235-239

Dhima KV, AS Lithourgidis, IB Vasilakoglou, CA Dordas (2007). Competition indices of common vetch and cereal intercrops in two seeding ratio. Field Crops Res 100:249-256

Eskandari H (2012). Yield and quality of forage produced in intercropping of maize (Zea mays L.) with cowpea (Vigna sinensis L.) and mungbean (Vigna radiate L.) as double cropped. J Basic Appl Sci Res 2:93-97

Evans J, AM McNeill, MJ Unkovich, NA Fettell, DP Heenan (2001). Net nitrogen balances for cool-season grain legume crops and contributions to wheat nitrogen uptake: A review. Aust J Exp Agric 41:347-359

Fentawa A (2006). Research achievements, gaps and directions in irrigation water management. In: Achievements and Priorities in Irrigation Water Management Research in Ethiopia with Particular Reference to Amhara Region Amhara Region Agricultural Research Institute, Bahir Dar (Ethiopia), 5-7 Dec 2005. Amhara Region Agricultural Research Institute, Bahir Dar, Ethiopia

Ghosh PK (2004). Growth, yield, competition and economics of groundnut/cereal fodder intercropping systems in the semi-arid tropics of India. Field Crops Res 88:227-237

Ginwal DS, R Kumar, H Ram, S Dutta, M Arjun, PS Hindoriya (2019). Fodder productivity and profitability of different maize and legume intercropping systems. Ind J Agric Sci 89:1451-1455

Imran M, A Ali, M Waseem, M Tahir, AU Mohsin, M Shehzad, A Ghaffari, H Rehman (2011). Bio-economic assessment of sunflower mungbean intercropping system at different planting geometry. Int Res J Agric Sci Soil Sci 1:126-136

Iqbal A, M Ayub, N Akbar, R Ahmad (2006). Growth and forage yield response of maize-legume mixed cropping to different sowing techniques. Pak J Agric Sci 43:126-130

Iqbal M, M Ahmad, WA Jehangir (1999). An assessment of livestock production potential in Pakistan: Implications for livestock sector policy [with comments]. Pak Dev Rev 38:615-628

Iqbal MA, A Iqbal (2015). Over viewing forage shortage for dairy animals and suitability of forage sorghum for ensiling. Glob Vet 14:173-177

Jan R, A Saxena, R Khanday, R Jan (2016). Intercropping indices and yield attributes of maize and black cowpea under various planting patterns. Intl Quart J Life Sci 11:1-7

Javanmard A, F Shekari, H Dehghanian (2014). Evaluation of forage yield and competition indices for intercropped barley and legumes. Intl $J$ Agric Biol Eng 8:193-196 
Khan A, F Munsif, K Akhtar, MZ Afridi, Z Ahmad, S Fahad, M Din (2014). Response of fodder maize to various levels of nitrogen and phosphorus. Amer J Plant Sci 5:2323-2329

Khan MB, M Khan, M Hussain, M Farooq, K Jabran, L Dong-Jin (2012). Bio-economic assessment of different wheat-canola intercropping systems. Intl J Agric Biol 14:14-19

Khonde P, RD Congo, K Tshiabukole, RD Congo, M Kankolongo, RD Congo, RD Congo (2018). Evaluation of yield and competition indices for intercropped eight maize varieties, soybean and cowpea in the zone of savanna of South-West RD Congo. Open Access Libr J 5:1-18

Machet JM, F Laurent, JY Chapot, T Dore, A Dulout (1997). Nitrogen control in intercrops and fallows, pp:271-288. Symposium-INRA, Cedex, France

Manna MC, PK Ghosh, CL Acharya (2003). Sustainable crop production through management of soil organic carbon in semiarid and tropical India. J Sustain Agric 21:85-114

Marer SB, BS Lingaraju, GB Shashidhara (2007). Productivity and economics of maize and pigeonpea intercropping under rainfed condition in northern transitional zone of Karnataka. Karnat J Agric Sci 20:1-3

Montgomery EG (1911). Correlation studies in corn. Neb Agric Exp Stn Аппи Rep 24:108-159
Moutonnet P (2002). Yield response factors of field crops to deficit irrigation. In: Deficit Irrigation Practices. FAO, Rome Italy

Nasrollahzadeh S, S Shaker-Koohi (2014). Effect of different intercropping patterns on yield and yield components of sorghum (Sorghum bicolor L.) and mungbean (Vigna radiate L.). Intl J Biosci 4:117123

Sani YGK, K Jamshidi, MRA Moghadam (2014). Evaluation of quality and quantity of corn and soybean grain yield in intercropping under deficit irrigation. Evaluation 4:133-139

Steel RGD, JH Torrie, DA Dickey (1997). Principles and Procedures of Statistics. A Biometrical Approach, pp:352-358. McGraw Hill Book Co. Inc, New York, USA

Takim (2012). Advantages of maize-cowpea intercropping over sole cropping through competition indices. J Agric Biodivers Res 1:53-59

Tofa A, T Ademulegun, R Solomon, H Shehu, L Omoigui (2019). Maizesoybean intercropping for sustainable intensification of cereallegume cropping systems in northern Nigeria. Exp Agric 55:73-87

Tsubo M, S Walker, HO Ogindo (2005). A simulation model of cereallegume intercropping systems for semi-arid regions: I. Model development. Field Crops Res 93:10-22

Yang C, Z Fan, Q Chai (2018). Agronomic and economic benefits of $\mathrm{pea} / \mathrm{maize}$ intercropping systems in relation to $\mathrm{N}$ fertilizer and maize density. Agron 8; Article 52 